Jelena Rusmirović ${ }^{\text {, Dragana Milošević }}{ }^{2}$, Zorica Veličić ${ }^{2}$, Milica Karanac ${ }^{1}$, Mustafa Kalifa ${ }^{3}$, Jovana Nikolić ${ }^{2}$, Aleksandar Marinkovic ${ }^{3 *}$

${ }^{1}$ University of Belgrade, Innovation Center of Faculty of Technology and Metallurgy, Belgrade, Serbia, ${ }^{2}$ University of Belgrade, Institute for Chemistry, Technology and Metallurgy, Belgrade, Serbia, ${ }^{3}$ University of Belgrade, Faculty of Techology and Metallurgy, Belgrade, Serbia
Scientific paper

ISSN 0351-9465, E-ISSN 2466-2585

UDC: 678.46 .004 .8

doi: $10.5937 /$ ZasMat1702189R

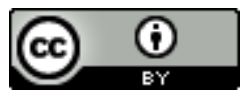

Zastita Materijala 58 (2)

189 - $197(2017)$

\title{
Production of rubber plasticizers based on waste PET: techno-economical aspect
}

\begin{abstract}
Production of rubber plasticizers, based on waste poly(ethylene terephthalate) (PET), and economic effectiveness of developed technologies are presented and discussed. Waste PET glycolyzates, named diisononyl terephthalate(DINTP), didecyl terephthalate (DDTP), dibenzyl terephthalate(DBTP) and diglyceryl terephthalate(DGTP), were obtained by catalytic depolymerization of PET with isononyl alcohol, decyl alcohol, benzyl alcohol and glycerol. The structural analysis of the synthesized plasticizers was done using elemental, FTIR and NMR spectral analysis. Physical-mechanical properties of the rubber products composed of 100 phr of $28 \%$ nitrile butadiene caoutchouc (NBR) and 20.7 phr of plasticizer were investigated. Influence of the synthesized plasticizers on Shore hardness, breaking strength and elongation at break was investigated. Obtained results were compared with ones obtained for commercial plasticizer dioctyl phthatale (DOP). Evaluation of economic potential of new technology for plasticizers production, i.e. results of techno-economic analysis, was presented. Benefits of the presented technology was based on the use of waste PET which is related to both environmental protection and profitability aspects.
\end{abstract}

Keywords: waste PET glycolysis, plasticizers, rubber, PET recycling.

\section{INTRODUCTION}

Poly(ethylene terephthalate) is a semicrystalline, thermoplastic polymer with excellent optical, barrier, thermal and mechanical properties [1, 2]. Accordingly, PET is widely used for three main applications categories: fibers, bottles and industrial use [2]. The consequence of using this material is formation of large amount of non-biodegradable PET waste. Environmental problems caused by incineration or accumulation of PET waste on landfills can be significantly reduced by chemical recycling of this material and its use for manufacturing new products, such as polyester, epoxy and alkyd resins [3-5] and plasticizers [6]. The recycling of waste PET can be primary (PreConsumer Industrial Scrap), secondary (Mechanical Recycling), tertiary (Chemical Recycling) and quaternary level (Energy Recovery) [7]. According to reusing possibility, recycling of waste PET is an

\footnotetext{
${ }^{*}$ Corresponding author: Aleksandar Marinković E-mail: marinko@tmf.bg.ac.rs

Paper received: 17. 02. 2017.

Paper accepted: 25. 03. 2017.

Paper is available on the website:

www.idk.org.rs/journal
}

economic activity - whether through material use or energy recovery. Economic benefits generated using waste or recycled materials outweigh the costs and improve productivity by reducing the use of expensive raw materials, whether metal in industry, or paper in commerce.

Nitrile butadiene caoutchouc (NBR), as one of the most widely used elastomer in the solid or latex state, is mostly manufactured by the emulsion polymerization method [8]. In rubber production, plasticizers are generally used to enhance rubber processability, as well as, to reduce rubber relaxation time in order to improve its physical-mechanical characteristics. Plasticizers used in the rubber industry are mainly diesters of dibasic acids and monohydroxy alcohols, and the most common are phthalates: di(2-ethylhexyl) phthalate, better known as dioctyl phthalate (DOP), di-isononylphthalate (DINP) and mixture of esters of aliphatic hydrophilic acids with high molecular weight and some types of polycondensed and polymerized products and chlorinated hydrocarbons [9]. Xia [10] et al. studied the synthesis of plasticizer dioctyl terephthalate (DOTP) using mixed purified terephthalic acid (PTA) and waste terephthalic acid as raw materials and octyl alcohol along with catalyst. Comparison of mechanical properties of DOTP with DOP it was 
concluded that DOTP have excellent performance and higher heat resistance. Considering the aspect of health impacts, DOP is a possible cancer causing agent in humans that increase cell proliferation, decrease apoptosis, oxidative damage, and selective clonal expansion of the initiated cells. Due to that, European Union (EU) banned the use of DOP along with several other phthalates in toys for young children. Strict regulation which limit further use of the most common DOP plasticizer create needs for development of new products with improved properties and competitive market cost.

It was shown that di-ethylene glycol terephthalate, obtained from PET waste by alcoholic glycolysis and further modified with maleic anhydride, shows good properties as plasticizer which gave material with good mechanical properties [11]. Generally, terephthalate based plasticizers indicate excellent durability in products, flexibility on low temperatures and better electrical insulation [12].

In this paper, the terephthalic acid moiety present in PET structure is used as source of dibasic acid in plasticizers synthesis. Presented recycling method proposes to make use of waste PET to produce value-added product/plasticizers: diisononyl terephthalate (DINTP), didecyl terephthalate (DDTP), dibenzyl terephthalate (DBTP) and diglyceryl terephthalate (DGTP). Plasticizers were obtained by a known method of catalytic depolymerization (transesterification) of PET with isononyl alcohol, decyl alcohol, benzyl alcohol and glycerol. The overall reaction involves substituting commercial phthalic anhydride with PTA which originates from waste PET. The physical-chemical properties of the obtained rubber products, based on DOP and PET based plasticiyers, were determined and compared. Plasticizers based on waste PET glycolyzates showed significant improvement of physical-mechanical properties in NBR products. In order to test the commercial viability of plasticizer technology the preliminary technoeconomic analysis was performed.

\section{EXPERIMENTAL}

\subsection{Materials}

Waste PET, used for unsaturated polyester resin production, was collected from soft beverage bottles. PET bottles were crushed into small pieces (app. $0.5 \times 0.5 \mathrm{~cm}$ ) and washed with ethanol and Table 1. Quantity of reactants used for syntheses of PET based plasticizers

Tabela 1. Količina reaktanata korišćenih za sinteze plastifikatora na bazi PET-a

\begin{tabular}{|c|c|c|c|c|c|c|c|c|}
\hline \multirow{2}{*}{ Reactant } & \multicolumn{2}{|c|}{ DINTP } & \multicolumn{2}{c|}{ DDTP } & \multicolumn{2}{c|}{ DBTP } & \multicolumn{2}{c|}{ DGTP } \\
\cline { 2 - 9 } & Weight, g & $\begin{array}{c}\text { Amount, } \\
\text { mol }\end{array}$ & Weight, g & $\begin{array}{c}\text { Amount, } \\
\text { mol }\end{array}$ & Weight, g & $\begin{array}{c}\text { Amount, } \\
\text { mol }\end{array}$ & Weight, g & $\begin{array}{c}\text { Amount, } \\
\text { mol }\end{array}$ \\
\hline PET & 92 & 0.48 & 92 & 0.48 & 92 & 0.48 & 80 & 0.41 \\
\hline INA & 170 & 1.19 & - & - & - & - & - & - \\
\hline DA & - & - & 170 & 1.19 & - & - & - & - \\
\hline BA & - & - & - & - & 75.4 & 0.69 & - & - \\
\hline Gly & - & - & - & - & - & - & 191 & 2.1 \\
\hline
\end{tabular}

dichloromethane to remove impurities and residual adhesives. m-Xylene, isononyl alcohol (INA), glycerol (Gly), benzyl alcohol (BA), decyl alcohol (DA), zinc oxide ( $\mathrm{ZnO})$, stearic acid and tetrabutyltitanate (TBT) were purchased from Sigma-Aldrich and were used without further purification.

Nitrile butadiene rubber (NBR), Europrene $\mathrm{N}$ $3980,28 \%$ acrylonitrile (AcN) content, was supplied from Versalis, Italy. Commercial rubber additives: Faktis - RheinChemie, Germany; VULKANOX MB-2/MG, mixture of 4- and 5-methyl2-mercapto-benzimidazole (MMBI), Lanxess, Germany; Carbon black Soot N -550 and Soot N - 660 (Scorpio Investment Ltd, Russian Federation); VULKANOL $\mathrm{FH}$, Xylene formaldehyde resin, Lanxess, Germany; Ultrasil VN - 3 is synthetically produced amorphous silicon dioxide (Evonik Industries, Germany); Sulfur, Eastman Chemical Company, Netherland; Vulkacit CBS amine based accelerator ( $\mathrm{N}$-cyclohexyl-2-benzothiazolesulfenamide) (Lanxess, Germany), and Vulkacit TMTD - tetramethylthiuram disulfide (Lanxess, Germany) was used as received. Dioctylphthalate (DOP) was supplied by BRENTAG CEE GMBH, Serbia.

\subsection{Plasticizer production}

General procedure used for glycolysis of waste $P E T$ : In three-necked round bottom flask of 500 $\mathrm{mL}$, equipped with magnetic stirrer, condenser, Dean-Stark separator and thermometer, certain amount of PET and alcohol were charged. Reaction mixture was heated to $115^{\circ} \mathrm{C}$ and maintained until the water evaporation was not observed, whereupon $0.4 \%$ of TBT catalyst was added and temperature was raised to $190{ }^{\circ} \mathrm{C}$. $m$-Xylene, $(3 \%$ on the reaction mixture), was used as the agent for azeotropic removal of ethylene glycol (EG). After completion of the synthesis obtained products was purified by removing residual reactants using vacuum distillation, hot product was filtered using diatomaceous earth and used for compounding of rubber products. Waste PET glycolysis products obtained by a catalytic depolymerization of PET with INA, DA, BA and Gly were designated DINTP, DDTP, DBTP and DGTP, respectively. Quantity of reactants used for syntheses of PET based plasticizers is given in Table 1. 


\subsection{Rubber production}

Rubber production was carried out in open system, two-roller mixer, and afterwards process was continued in closed system, mixer, and recently the twin-screw extruder of great length was used. Technological procedure consists of two

Table 2. Rubber products composition with 20.7 phr of plasticizers based on NBR $28 \%$ (the amount of all formulation components is given in phr)

Tebela 2. Sastav proizvoda od gume baziranih na 28\% NBR elastomeru sa dodatkom 20,7 phr plastifikatora (količina komponenata u formulaciji je data u phr vrednostima)

\begin{tabular}{|l|c|c|c|c|c|}
\hline \multicolumn{1}{|c|}{ Formulation/ Sample designation } & 0 & 1 & 2 & 3 & 4 \\
\hline NBR 28\% & phr & phr & phr & phr & phr \\
\hline Plasticizer & DOP & DINTP & DDTP & DBTP & DGTP \\
\hline NBR 28\% & 100 & 100 & 100 & 100 & 100 \\
\hline Stearic acid & 1.5 & 1.5 & 1.5 & 1.5 & 1.5 \\
\hline Faktis & 5.2 & 5.2 & 5.2 & 5.2 & 5.2 \\
\hline VULKANOX MB-2/MG & 2.5 & 2.5 & 2.5 & 2.5 & 2.5 \\
\hline Carbon black N-550 & 52 & 52 & 52 & 52 & 52 \\
\hline VULKANOL FH & 5.2 & 5.2 & 5.2 & 5.2 & 5.2 \\
\hline Plasticizer & 20.7 & 20.7 & 20.7 & 20.7 & 20.7 \\
\hline ZnO & 5.2 & 5.2 & 5.2 & 5.2 & 5.2 \\
\hline Sulfur & 2.8 & 2.8 & 2.8 & 2.8 & 2.8 \\
\hline VULKACIT CBS & 1.6 & 1.6 & 1.6 & 1.6 & 1.6 \\
\hline VULKACIT TMTD & 0.35 & 0.35 & 0.35 & 0.35 & 0.35 \\
\hline
\end{tabular}

Indexes from 0 - 4 (Table 2) designate rubber formulations in which commercial plasticizer DOP (0) and PET based plasticizers: DINTP (1), DDTP (2), DBTP (3) and DGTP (4), respectively, were used. In order to investigate influence of the synthesized plasticizers on physical-mechanical properties of NBR rubber based products, the replacement of DOP with synthesized PET based plasticizers was performed. The samples of rubber products, after standing for $24 \mathrm{~h}$, were cutted into a defined specimen according to standrads, and tested their mechanical properties (Table 3 ).

\subsection{Characterization methods}

Structural analysis of synthesized compounds was performed by FTIR, ${ }^{1} \mathrm{H}$ NMR and ${ }^{13} \mathrm{C}$ NMR spectroscopy. FTIR spectra were recorded on Bomem MB 100 spectrometer, within a range of $400-4000 \mathrm{~cm}^{-1}$. ${ }^{1} \mathrm{H}$ NMR and ${ }^{13} \mathrm{C}$ NMR spectra of synthesized compounds were recorded by Bruker AC 250 instrument using chloroform-d $\left(\mathrm{CDCl}_{3}\right)$ as internal standard. Chemical shifts $(\delta)$ are expressed in ppm relative to TMS $\left(\delta_{H}=0 \mathrm{ppm}\right)$ in ${ }^{1} \mathrm{H}$ NMR spectra or the residual solvent signal $\left(\delta_{\mathrm{C}}=\right.$ $39.5 \mathrm{ppm})$ in the ${ }^{13} \mathrm{C}$ NMR spectra. Elemental analysis was performed using Vario EL III Elemental analyzer. Rheological behavior was followed by Rheometer 2000, Monsanto, with oscillating disc. The standard methods applied for determination of the mechanical properties of obtained rubber product are given in Table 3 . phases: production of base without sulfur and accelerators, and after 24 hours and mixing base with appropriate amounts of sulfur and accelerators. Formulations of rubber products with $20.7 \mathrm{phr}$ of commercial (DOP) and synthesized PET based plasticizers are shown in Table 2.
Determination of indentation hardness of a durometer (hardness Shore A) of the obtained samples was scaled in degree $(1-100)$.

Breaking strength, elongation at break and Stress at $100 \%$ and $300 \%$ elongation of rubber samples were performed using an $A G-X$ plus Universal testing machine, Shimadzu. All tests were performed at room temperature adjusted at crosshead speed of $0.5 \mathrm{~mm} / \mathrm{min}$.

Table 3. The standard methods used for determination of physico-mechanical characteristic of rubber product

Tabela 3. Standardne metode korišćene za određivanje fizičko-mehaničkih svojstava proizvoda od gume

\begin{tabular}{|l|c|c|}
\hline \multicolumn{1}{|c|}{$\begin{array}{c}\text { Physico-mechanical } \\
\text { characteristic of rubber }\end{array}$} & \multicolumn{2}{|c|}{ Standard } \\
\hline Shore hardness ('ShA) & SRPS & DIN \\
& G.S2.125 & 53505 \\
\hline Breaking strength (MPa) & SRPS & ISO \\
& G.S2.127 & 37 \\
\hline Stress at 100\% & SRPS & ISO \\
elongation (MPa) & G.S2.127 & 37 \\
\hline Stress at 300\% & SRPS & ISO \\
elongation (MPa) & G.S2.127 & 37 \\
\hline Elongation at break (\%) & SRPS & DIN \\
& G.S2.127 & 53479 \\
\hline Specific gravity & ASTM D792 & ISO \\
& & 1183 \\
\hline
\end{tabular}




\section{RESULTS AND DISSCUSION}

\subsection{Characterization of plasticizers}

Various products/monomers can be obtained by catalytic depolymerization of waste PET using different glycols like ethylene glycol, diethylene glycol, propylene glycol, polyethylene glycol, 1,4butanediol, etc. [13]. In this work the products of glycolysis were obtained by the transesterification of PET with INA, DA, BA or Gly, leading to chain fragmentation and the formation of the corresponding ester of terephthalic acid. Yield and melting points of synthesized PET based plastisticizers are shown in Table 4. Structural formulas of the synthesized DINTP, DDTP, DBTP and DGTP are shown in Figure 1.
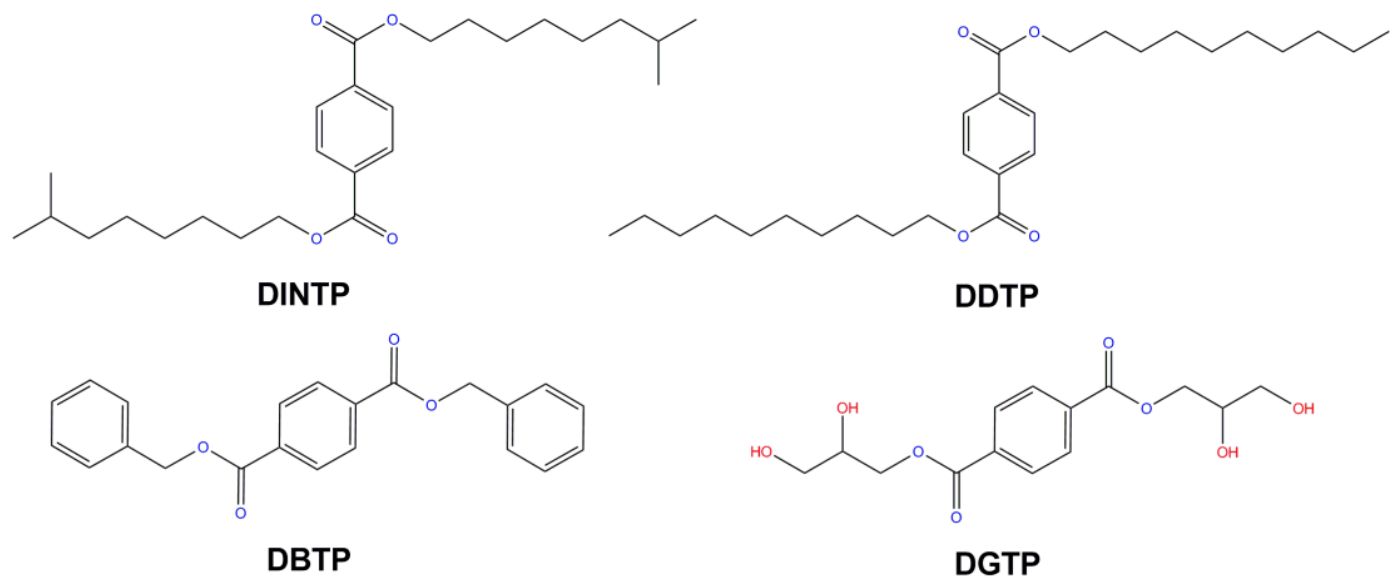

DDTP

Figure 1. Structural formulas of the synthesized DINTP, DDTP, DBTP and DGTP

Slika 1. Strukturne formule sintetisanih DINTP, DDTP, DBTP i DGTP

Table 4. Yield and melting points of synthesized PET based plastisticizers

Tabela 4. Prinos i tačke topljenja sintetisanih plastifikatora na bazi PET-a

\begin{tabular}{|c|c|c|c|}
\hline Plasticizer & Yiled (\%) & \multicolumn{2}{|c|}{ Melting point (ㅇ) } \\
\hline DINTP & & Experimental & $46^{14}$ \\
\hline DDTP & 91 & $44-5$ & $57^{14}$ \\
\hline DBTP & 89 & $55-6$ & $94^{15}$ \\
\hline DGTP & 96 & $92-3$ & - \\
\hline
\end{tabular}

Results of FTIR analysis of the synthesized DINTP, DDTP, DBTP and DGTP are given in Table 5.

Table 5. Results of FTIR analysis of the synthesized DINTP, DDTP, DBTP and DGTP

Tabela 5. Rezultati FTIR analize sintetisanih DINTP, DDTP, DBTP i DGTP

\begin{tabular}{|c|c|c|c|c|c|c|c|c|c|c|c|}
\hline Sample & $\begin{array}{c}\mathrm{V}_{\mathrm{as}} \\
\left(\mathrm{CH}_{3}\right), \\
\mathrm{cm}^{-1}\end{array}$ & $\begin{array}{c}\mathrm{V}_{\mathrm{s}} \\
\left(\mathrm{CH}_{3}\right), \\
\mathrm{cm}^{-1}\end{array}$ & $\begin{array}{c}\delta_{\mathrm{as}} \\
\left(\mathrm{CH}_{3}\right), \\
\mathrm{cm}^{-1}\end{array}$ & $\begin{array}{c}\delta_{\mathrm{s}} \\
\left(\mathrm{CH}_{3}\right), \\
\mathrm{cm}^{-1}\end{array}$ & $\begin{array}{c}\mathrm{V}_{\mathrm{as}} \\
\left(\mathrm{CH}_{2}\right), \\
\mathrm{cm}^{-1}\end{array}$ & $\begin{array}{c}\mathrm{V}_{\mathrm{s}} \\
\left(\mathrm{CH}_{2}\right), \\
\mathrm{cm}^{-1}\end{array}$ & $\begin{array}{c}\mathrm{V} \\
(\mathrm{C}=\mathrm{O}), \\
\mathrm{cm}^{-1}\end{array}$ & $\begin{array}{c}\mathrm{V}_{\mathrm{s}} \\
(\mathrm{C}-\mathrm{O}) \\
\mathrm{cm}^{-1}\end{array}$ & $\begin{array}{c}\mathrm{V}_{\mathrm{as}} \\
(\mathrm{C}-\mathrm{O}) \\
\mathrm{cm}^{-1}\end{array}$ & $\begin{array}{c}\mathrm{v} \\
(\mathrm{C}=\mathrm{C}), \\
\mathrm{cm}^{-1}\end{array}$ & $\begin{array}{c}\mathrm{V} \\
(\mathrm{CH})_{\mathrm{ar}} \\
\mathrm{cm}^{-1}\end{array}$ \\
\hline DINTP & 2961 & 2875 & 1451 & 1378 & 2927 & 2854 & 1720 & 1117 & 1259 & $\begin{array}{c}1600- \\
1450\end{array}$ & 2905 \\
\hline DDTP & 2959 & 2873 & 1448 & 1372 & 2929 & 2850 & 1722 & 1110 & 1255 & $\begin{array}{c}1600- \\
1450\end{array}$ & 2900 \\
\hline DBTP & - & - & - & - & - & - & 1724 & 1102 & 1270 & $\begin{array}{c}1600- \\
1450\end{array}$ & 2905 \\
\hline DGTP & - & - & - & - & 2925 & 2845 & 1723 & 1015 & 1268 & $\begin{array}{c}1600- \\
1450\end{array}$ & 2905 \\
\hline
\end{tabular}

Results of NMR analysis of the synthesized DINTP, DDTP, DBTP and DGTP:

DINTP

${ }^{1} \mathrm{H}$ NMR $\left(\mathrm{CDCl}_{3}\right): 0.92\left(t, 12 \mathrm{H},-\mathrm{O}\left(\mathrm{CH}_{2}\right)_{6} \mathrm{CH}\left(\mathrm{CH}_{3}\right) \mathrm{CH}_{3}\right), 1.24\left(m, 4 \mathrm{H},-\mathrm{O}\left(\mathrm{CH}_{2}\right)_{5} \mathrm{CH}_{2} \mathrm{CH}\left(\mathrm{CH}_{3}\right)_{2}\right), 1.30(m$, $\left.8 \mathrm{H},-\mathrm{O}\left(\mathrm{CH}_{2}\right)_{3} \mathrm{CH}_{2} \mathrm{CH}_{2} \mathrm{CH}_{2}-\right), 1.44\left(m, 4 \mathrm{H},-\mathrm{OCH}_{2} \mathrm{CH}_{2} \mathrm{CH}_{2}-\right), 1.82\left(m, 4 \mathrm{H},-\mathrm{OCH}_{2} \mathrm{CH}_{2-}\right), 4.40(t, \mathrm{~J}=6.1 \mathrm{~Hz}$, $\left.4 \mathrm{H}, \mathrm{O}-\mathrm{CH}_{2}-\mathrm{CH}_{2}-\right), 7.89\left(\mathrm{~m}, 4 \mathrm{H}, \mathrm{H}_{\mathrm{Ph}}\right) ;{ }^{13} \mathrm{C} \mathrm{NMR}\left(\mathrm{CDCl}_{3}\right): 23.1\left(-\mathrm{O}\left(\mathrm{CH}_{2}\right)_{6} \mathrm{CH}\left(\mathrm{CH}_{3}\right) \underline{\mathrm{CH}}_{3}\right), 25.1\left(-\mathrm{OCH}_{2} \mathrm{CH}_{2-}\right.$ $\left.\underline{\mathrm{C}} \mathrm{H}_{2}\left(\mathrm{CH}_{2}\right)_{3} \mathrm{CH}\left(\mathrm{CH}_{3}\right)_{2}\right), 26.9\left(-\mathrm{O}\left(\mathrm{CH}_{2}\right)_{3} \mathrm{CH}_{2} \mathrm{CH}_{2} \mathrm{CH}\left(\mathrm{CH}_{3}\right)_{2}\right), 29.9\left(-\mathrm{OCH}_{2} \mathrm{CH}_{2}-\mathrm{CH}_{2} \underline{\mathrm{CH}_{2}} \mathrm{CH}_{2} \mathrm{CH}_{2} \mathrm{CH}\left(\mathrm{CH}_{3}\right)-\mathrm{CH}_{3}\right)$, $32.0\left(-\mathrm{OCH}_{2} \underline{\mathrm{CH}_{2}} \mathrm{CH}_{2} \mathrm{CH}_{2} \mathrm{CH}_{2} \mathrm{CH}_{2} \mathrm{CH}\left(\mathrm{CH}_{3}\right)_{2}\right)$, $39.2\left(-\mathrm{O}_{2} \mathrm{H}_{2}\left(\mathrm{CH}_{2}\right)_{4} \mathrm{CH}\left(\mathrm{CH}_{3}\right)_{2}\right)$, $129.6\left(\mathrm{CH}_{\mathrm{Ph}}\right), 134.4\left(\mathrm{C}_{\mathrm{Ph}}\right)$, $166.0(\mathrm{C}=\mathrm{O})$; 


\section{DDTP}

${ }^{1} \mathrm{H}$ NMR $\left(\mathrm{CDCl}_{3}\right): 0.88\left(t, J=7.4 \mathrm{~Hz}, 6 \mathrm{H},-\mathrm{OCH}-\left(\mathrm{CH}_{2}\right)_{8} \mathrm{CH}_{3}\right), 1.27\left(m, 4 \mathrm{H},-\mathrm{OCH}_{2}\left(\mathrm{CH}_{2}\right)_{2}\left(\mathrm{CH}_{2}\right)_{n} \mathrm{CH}_{3}\right), 1.30(m$, $\left.16 \mathrm{H}, \quad-\mathrm{OCH}_{2} \mathrm{CH}_{2}\left(\mathrm{CH}_{2}\right)_{4} \mathrm{CH}_{2} \mathrm{CH}_{3}\right), \quad 1.33 \quad\left(\mathrm{~m}, \quad 4 \mathrm{H}, \quad-\mathrm{OCH}_{2}\left(\mathrm{CH}_{2}\right)_{7} \mathrm{CH}_{2} \mathrm{CH}_{3}\right), \quad 1.46 \quad(\mathrm{~m}, \quad 4 \mathrm{H}, \quad-$ $\left.\mathrm{OCH}_{2} \mathrm{CH}_{2} \mathrm{CH}_{2}\left(\mathrm{CH}_{2}\right)_{6} \mathrm{CH}_{3}\right), 1.87\left(\mathrm{~m}, 4 \mathrm{H},-\mathrm{OCH}_{2} \mathrm{CH}_{2}\left(\mathrm{CH}_{2}\right)_{7} \mathrm{CH}_{3}\right), 4.31\left(\mathrm{~m}, 4 \mathrm{H},-\mathrm{OCH}_{2} \mathrm{CH}_{2}\left(\mathrm{CH}_{2}\right)_{7} \mathrm{CH}_{3}\right), 7.96$ (m, 4H, Hen $) ;{ }^{13} \mathrm{C}$ NMR $\left.\left(\mathrm{CDCl}_{3}\right): 14.3\left(-\mathrm{OCH}_{2}\left(\mathrm{CH}_{2}\right)_{8} \mathrm{CH}_{3}\right), 23.2-\mathrm{OCH}_{2}\left(\mathrm{CH}_{2}\right)_{7} \mathrm{CH}_{2} \mathrm{CH}_{3}\right), 25.7\left(-\mathrm{OCH}_{2} \mathrm{CH}_{2}-\right.$ $\left.\underline{\mathrm{C}} \mathrm{H}_{2}\left(\mathrm{CH}_{2}\right)_{6} \mathrm{CH}_{3}\right), 29.1\left(-\mathrm{OCH}_{2} \mathrm{CH}_{2} \mathrm{CH}_{2} \mathrm{CH}_{2} \mathrm{CH}_{2} \mathrm{CH}_{2} \underline{\mathrm{CH}_{2}} \mathrm{CH}_{2} \mathrm{CH}_{2} \mathrm{CH}_{3}\right), 29.8\left(-\mathrm{O}\left(\mathrm{CH}_{2}\right)_{4}-\underline{\mathrm{CH}_{2}} \underline{\mathrm{C}} \mathrm{H}_{2}\left(\mathrm{CH}_{2}\right)_{3} \mathrm{CH} 3\right)$, $31.6\left(-\mathrm{OCH}_{2} \mathrm{CH}_{2}\left(\mathrm{CH}_{2}\right)_{7} \mathrm{CH}_{3}\right), 65.2\left(-\mathrm{O}_{2} \mathrm{H}_{2} \mathrm{CH}_{2}\left(\mathrm{CH}_{2}\right)_{7} \mathrm{CH}_{3}\right), 130.1\left(\mathrm{C}_{\mathrm{Ph}}\right), 134.8\left(\mathrm{C}_{\mathrm{Ph}}\right), 166.1(\mathrm{C}=\mathrm{O})$.

\section{DBTP}

${ }^{1} \mathrm{H}$ NMR $\left(\mathrm{CDCl}_{3}\right): 5.26\left(2 \mathrm{H}, \mathrm{C}_{6} \mathrm{H}_{5}-\mathrm{CH}_{2^{-}}\right), 7.38\left(t, 3 \mathrm{H}, \mathrm{H}_{\mathrm{Ph}}\right), 7.47\left(d, 2 \mathrm{H}, \mathrm{H}_{\mathrm{Ph}}\right), 7.83\left(\mathrm{~m}, 4 \mathrm{H}, \mathrm{H}_{\mathrm{Ph}}\right) ;{ }^{13} \mathrm{C} \mathrm{NMR}$ $\left(\mathrm{CDCl}_{3}\right): 65.7\left(\mathrm{C}_{6} \mathrm{H}_{5}-\underline{\mathrm{C}}_{2}-\right), 127.1\left(\mathrm{C}_{\mathrm{Ph}}\right), 127.6\left(\mathrm{C}_{\mathrm{Ph}}\right), 128.9\left(\mathrm{C}_{\mathrm{Ph}}\right), 129.8\left(\mathrm{C}_{\mathrm{Ph}}\right), 134.4\left(\mathrm{C}_{\mathrm{Ph}}\right), 136.1\left(\mathrm{C}_{\mathrm{Ph}}\right)$, $165.9(\underline{\mathrm{C}}=\mathrm{O})$.

\section{DGTP}

${ }^{1} \mathrm{H}$ NMR $\left(\mathrm{CDCl}_{3}\right): 3.56\left(t, 2 \mathrm{H}, \mathrm{OH}-\mathrm{CH}_{2}\right), 3.58(d, 1 \mathrm{H}, \mathrm{OH}-), 3.65(t, 1 \mathrm{H}, \mathrm{OH}-), 3.81\left(t, 2 \mathrm{H}, \mathrm{HOCH}_{2}\right), 3.90(m$, $\left.1 \mathrm{H},-\mathrm{CH}_{2} \mathrm{CHOH}\right), 4.28\left(d, 2 \mathrm{H},-\mathrm{OCH}_{2}-\right), 4.53\left(d, 2 \mathrm{H},-\mathrm{OCH}_{2}\right), 7.83\left(\mathrm{~m}, 4 \mathrm{H}, \mathrm{Ph}^{2}\right) ;{ }^{13} \mathrm{C}$ NMR $\left(\mathrm{CDCl}_{3}\right): 63.7$ $\left(\mathrm{HO} \underline{\mathrm{C}} \mathrm{H}_{2}\right), 65.6\left(-\mathrm{O}_{\mathrm{CH}} \mathrm{2}^{-}\right), 70.9\left(\mathrm{CH}_{2} \underline{\mathrm{C}} \mathrm{HOH}\right), 129.8\left(\mathrm{C}_{\mathrm{Ph}}\right), 134.4\left(\mathrm{C}_{\mathrm{Ph}}\right), 165.9(\underline{\mathrm{C}}=\mathrm{O})$.

Results of elemental analysis of the synthesized DINTP, DDTP, DBTP and DGTP are shown in Table 6.

Table 6. Results of elemental analysisof the synthesized DINTP, DDTP, DBTP and DGTP

Tabela 6. Rezultati elementalne analize sintetisanih DINTP, DDTP, DBTP i DGTP

\begin{tabular}{|c|c|c|c|c|}
\hline Method & & $\% \mathrm{C}$ & $\% \mathrm{H}$ & $\% \mathrm{O}$ \\
\hline \multirow{2}{*}{ DINTP } & Exp. & 74.55 & 10.08 & 15.37 \\
\cline { 2 - 5 } & Calc. & 74.60 & 10.11 & 15.29 \\
\hline \multirow{2}{*}{ DDTP } & Exp. & 75.24 & 10.32 & 15.44 \\
\cline { 2 - 5 } & Calc. & 75.29 & 10.38 & 14.33 \\
\hline \multirow{2}{*}{ DBTP } & Exp. & 76.24 & 5.22 & 18.55 \\
\cline { 2 - 5 } & Calc. & 76.29 & 5.24 & 18.48 \\
\hline \multirow{2}{*}{ DGTP } & Exp. & 53.47 & 5.79 & 40.74 \\
\cline { 2 - 5 } & Calc. & 53.50 & 5.77 & 40.73 \\
\hline
\end{tabular}

\subsection{Mechanical properties of rubber products}

Physico-mechanical properties of rubber products obtained with commercial plasticizer (DOP) and ones synthesized from waste PET (Figure 2) are presented in Table 7. As it can be seen, products that contain plasticizers from waste PET showed similar processability in comparison to Table 7 - Physical-mechanical properties of rubber products

Tabela 7. Fizičko-mehanička svojstva proizvoda od gume

\begin{tabular}{|l|c|c|c|c|c|}
\hline \multicolumn{1}{|c|}{ Physico-mechnaical properties } & $\mathbf{0}$ & $\mathbf{1}$ & $\mathbf{2}$ & $\mathbf{3}$ & $\mathbf{4}$ \\
\hline Shore hardness ( $\left.{ }^{\circ} \mathrm{ShA}\right)$ & 56 & 56 & 65 & 64 & 64 \\
\hline Breaking strength (MPa) & 11 & 12 & 13 & 14 & 12 \\
\hline Modulus 100\% & 1.6 & 1.8 & 2.8 & 2.1 & 2.5 \\
\hline Modulud 300\% & 8.7 & 9.3 & 10.1 & 10.5 & 11.3 \\
\hline Elongation at break (\%) & 370 & 384 & 390 & 400 & 320 \\
\hline Specific gravity $\left(\mathrm{g} / \mathrm{cm}^{3}\right)$ & 1.20 & 1.18 & 1.19 & 1.20 & 1.20 \\
\hline
\end{tabular}

As it can be seen from physico-mechanical properties, the obtained products containing the products obtained with commercial plasticizer (DOP). However, properties of rubber vulcanizates are improved: Shore hardness, modulus, breaking strength increased, while elongation at break was decreased for rubber product based on DGTP.

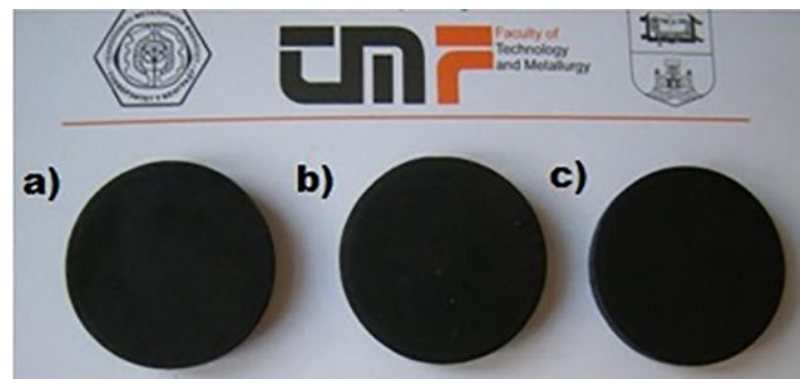

Figure 2. Tested rubber products with a) DINTP, b) DBTP and c) DGTP plasticizer

Slika 2. Testirani gumeni proizvodi sa plastifikatorima a) DINTP, b) DBTP i c) DGTP

Results of rubber product physical-mechanical tests, obtained materials can be compared with standard, commercial plasticizers (DOP), but PET based plasticizers are preferred because during the processing they act as plasticizers and after vulcanization as reinforcing materials. plasticizers from waste PET have better physical and mechanical properties compared to those 
containing commercial plasticizer DOP: hardness, modulus and breaking strength increase, while elongation at break decreases. These results clearly show that plasticizers from PET in NBR mixtures act as a plasticizers, while after vulcanization act as a reinforcing material.

\subsection{Rheological properties of rubber products}

The rheological properties of the mixture of raw NBR (Figure 3) show the rheological behavior of the compositions of NBR products plasticized with DOP and synthesized plasticizers. A rheological property of rubber products depends on rubber formulation. According to that, rubber formulations that contain plasticizers based on waste PET were designed to adjust properties of the products in relation to required condition of use. The reactive sites, i.e. curing sites, are allylic hydrogens adjacent to carbon-carbon double bonds. In the course of vulcanization, these atoms are replaced by sulfur chains, containing between one and eight atoms, linked to another polymer chain. The number of sulfur atoms in the crosslink strongly influences the physical properties of the final rubber article. Short cross-links give the rubber

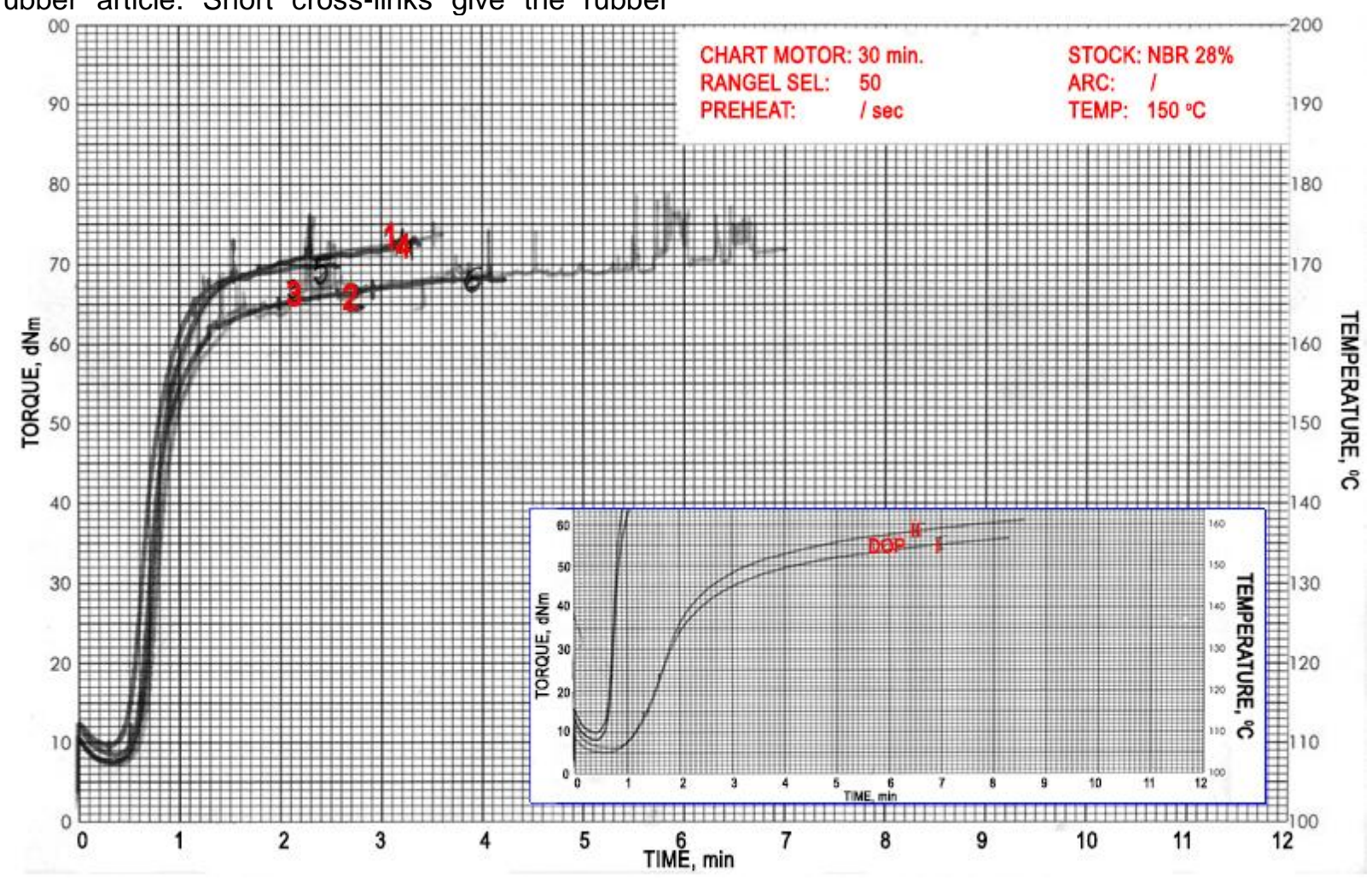

Figure 3. Rheological curves of NBR rubber product based on DOP and PET derived plasticizers Slika 3. Reološke krive NBR gumenih proizvoda baziranih na DOP i PET derivatima plastifikatora

Vulcanization process is characterized by three stages: induction period, networking reaction, and changes in developed network. The vulcanization rate is controlled by the processes take place in second stage, and the total vulcanization time is a sum of first and second stages. As it can be seen better heat resistance, while longer connection gives the rubber good dynamic properties. Dynamic properties are important for flexing movements of the rubber article, e.g., the movement of a side-wall of a running tire. Without good flexibility these movements cause crack formation and deterioration of the properties of rubber product. Vulcanization is a key process of rubber-production technology due to high energy and process time demands. Vulcanization process, shown by vulcanization curves (Figure 3 ), allows determination of optimum production-related technical conditions and control of product properties. Vulcameter automatically respond to vulcanization process for each specimen, and obtained curve represents the dynamic shear modulus of cyclically stressed test specimen during vulcanization. Hence, it allows not only determination of technologically important data, but also sufficiently accurate velocity constants of individual vulcanization stages and their respective activation energies. In accordance with that appropriate vulcanization curves of all investigated systems (Table 2) are given on Figure 3. from the rheological curves (Figure 3 ), in induction period, there is no measurable difference in behavior among the studied NBR mixtures, i.e. show in that region low contribution of all tested softeners to flow properties, and safe processing properties of the mixtures. For all samples, the 
chemical reactions in the course of induction period are slow which is beneficial for safe processing and forming of design geometrical feature of products, i.e. spreading inside the mould (Figure 2). The second stage of the rheological curves shows the speed of vulcanization (vertical lines at Figure 3), as it can be noticed, even in this area, there is no measurable difference between the curves because the cross-linking reactionis characterized by creation of network.

However, the last stage of chemical crosslinking reactions depend on the rubber type, vulcanization system and temperature. From the vulcanization curves it could be observed that third stage mainly reflect contribution of the plasticizer used on vulcanization characteristics of product. All softeners show greater resistance to drive oscillations in the remoter (shearing moment), which means that the internal structure of vulcanizates - composites is stronger. These differences can be clearly seen from physical and mechanical properties of vulcanized rubber containing softener (Table 7).

\subsection{Techno-economic analysis}

The techno-economic analysis is a complex procedure and generally includes two categories:

Table 8. Definition of fixed and variable costs on a monthly basis of DGTP production

Tabela 8. Definisanje fiksnih i varijabilnih troškova proizvodnje DGTP na mesečnom nivou

\begin{tabular}{|l|c|c|c|}
\hline \multicolumn{2}{|c|}{ Monthly fixed costs $(€)$} & \multicolumn{2}{c|}{ Monthly variable costs (5.6 t/day), $€$} \\
\hline Constructions & 433 & Raw materials ${ }^{\star *}$ & 94020 \\
\hline Funds for the operation & 2121 & Fuels & 170 \\
\hline Light energy & 712 & Electric power for the reactor & 3000 \\
\hline Workforce & 8000 & Transport & 1000 \\
\hline Sales and marketing expenses & 1500 & Packaging & 10100 \\
\hline Other fixed expenses & 350 & & \\
\hline Bookkeeping and maintenance & 1000 & & 108290 \\
\hline Research and development & 1500 & & 123907 \\
\hline Total fixed costs (€) & 15617 & Total variable costs (€) & 4130 \\
\hline $\begin{array}{l}\text { The breakeven (monthly } \\
\text { turnover) (€) }\end{array}$ & & & 5369 \\
\hline Daily turnover (profitability) $(€)$ & & & 37172 \\
\hline Daily turnover (planned) $(€)$ & & & \\
\hline Profit per month & & & \\
\hline
\end{tabular}

"REACTOR 279240€; two tanks (V=200t) 80000€; pump 2000€; decanting tank 2000€; transformer substation 2000€; cooling tower $10000 €$; fire protection $50000 €$; waste water treatment $10000 €$; compressor $20000 €$; two tanks $(\mathrm{V}=100 \mathrm{t})$ $30000 €$; centrifugal pump $4000 €$ (Total 509240€); period of amortization of operation funds - 20 years; period of amortization of buildings - 50 years.

"Raw materials: Waste PET - 400€/t; Gly - 700€/t.

Analogously,monthly fixed and variable costs and breakeven point of DINTP, DDTP and DBTP are calculated (alcohol price: INA - 1700€/t; DA $2700 € / t ; B A-2100 € / t)$. The preliminary technoeconomic analysis (Table 8 ) showed that the capital and maintenance/operational (MO) cost. Design of technology provides data necessary for calculation of the values of capital investment (equipment, construction, installation, etc.). MO cost elements of different rubber technologies such chemicals, labor and energy cost are of different values in techno-economic analysis. Due to this, selection of the most influential factors, without sacrificing validity of assessments, was made.

Techno-economic analysis of the plasticizer production (DINTP, DDTP, DBTP, DGTP), performed by calculation of monthly fixed and variable costs, as well as the breakeven point, was done with the aim of determination of the profitability and economic benefit of the implemented plasticizer production. Profitability is one of the main objectives of the production success and realization of production. Monthly need for plasticizers in the Serbian market amounts 168 that is in accordance to the Serbian market needs. Techno-economic analysis was done for plasticizer production carried out in plant designed for $5.6 \mathrm{t}$ /day batch previously described in literature [16]. Monthly fixed and variable costs as well as breakeven point of DGTP are presented in Table 8. 
However, economic benefit of presented plasticizer technology refers to the waste input raw materials such as PET or Gly (BioDiesel byproduct) which reduces the cost of raw materials and waste storage costs. Total monthly fixed and variable costs of DGTP production amount $123907 €$. In order to make plasticizer technology profitable it is necessary to achieve $5369 €$ daily earnings. Those production capacity makes $1239 €$ daily and 37172 $€$ monthly profit, respectively. The calculated cost prices of the DINTP, DDTP and DBTP plasticizers that ensure production profit are shown in Table 9.

Table 9. The cost prices of the commercial and plasticizers based on waste PET

Tabela 9. Cene troškova komercijalnih plastifikatora i plastifikatora baziranih na otpadnom PET-u

\begin{tabular}{|l|c|}
\hline \multicolumn{1}{|c|}{ Plasticizer } & Cost price, $€ / \mathrm{kg}$ \\
\hline Commercial DOP & 1.3 \\
\hline Commercial DINTP & 1.7 \\
\hline DINTP & 1.7 \\
\hline DDTP & 2.3 \\
\hline DBTP & 1.6 \\
\hline
\end{tabular}

Consideration the calculated cost prices of the DINTP, DDTP and DBTP plasticizers (Table 9) and comparison with commercial DOP and DINTP cost prices it can be concluded that the DINTP plasticizer technology is competitive with commercial DINP, but first one brings benefits of ecological issue. DBTP production technology is competitive with commercial DINTP; while commercial DOP has more favorable market prices but uncertain future, i.e. EU banned the use of DOP along with several other phthalates in toys for young children, and this trend of falling consumption will be more pronounced in the future. According to the presented results it can be seen that waste PET plasticizes technology can be economically viable and thus it is reasonably to be implemented in a industrial processes with high probability of return of investment for short period with achievement of good profitability.

\section{CONCLUSION}

The aim of this work was to investigate of new plasticizersproduction technology, based on waste PET and INA, DA, BA and Gly. Obtained materials were compared with commercial plasticizers DOP. Results of physico-mechanical investigation of rubber product showed that PET based plasticizers in NBR $28 \%$ rubber mixture act as plasticizers during processing of rubber mixtures and after vulcanization as reinforcing materials. After confirming the application and production of rubber products it was performed techno-economic analysis in order to determine the economic benefits of plasticizer production and application. Two main points could be achieved by implementation of developed technology: higher product quality and satisfactory/improved technoeconomic criteria which proved needs for implementation in a real production processes.

The preliminary techno-economic analysis showed that the waste PET plasticizers production is economically viable and bring multiple benefits, which is reflected in the profit and reducing waste disposal costs. Positive NVP values for quarterly overview confirm that plasticizers production is economically acceptable concept which could give significant contribution to lower expenses of raw material, by using waste PET, which contribute in a financial structure. However, environmental and economic benefit of recycling and reused of waste PET was reflected in prevention of pollution by reducing the need of using of new raw materials, energy saving, reduction of greenhouse gas emissions that contribute to global climate change and save money thought the lower cost of the raw materials.

\section{REFERENCES}

[1] E.Baştürk, S.Madakbaş, B.Karadoğan, M.V. Kahraman (2016) Preparation and thermal properties of polyethylene terephthalate/huntitehydromagnesite composites, Polymer Composites, 37(11), 3275-3279.

[2] L.N.Ji (2013) Study on Preparation Process and Properties of Polyethylene Terephthalate (PET), Applied Mechanics and Materials, 312(3), 406-410.

[3] J.M.L.Reis (2011) Effect of aging on the fracture mechanics of unsaturated polyester based on recycled PET polymer concrete, Materials Science and Engineering A, 528(6) 3007-3009.

[4] A.M.Atta, M.E.Abdel-Raouf, S.M.Elsaeed, A.A.A. Abdel-Azim (2006) Curable resins based on recycled poly(ethylene terephthalate) for coating applications, Progress in Organic Coatings, 55(1), 50-59.

[5] G.Güçlü, M.Orba (2009) Alkyd resins synthesized from postconsumer PET bottles, Progress in Organic Coatings, 65(3), 362-365.

[6] S.Kilinc, T.B.lyim, S.Emik, S.Ozgumus (2005) Recycling of waste PET: Usage as secondary plasticizer for PVC, Polymer-Plastics Technology and Engineering, 44(8-9), 1379-1388.

[7] P.G.Karayannidis, S.D.Achilias (2007) Chemical Recycling of Poly(ethylene terephthalate), Macromolecular Materials and Engineering, 292(2), 128-146.

[8] W.G.Hwang, K.H.Wei, C.M.Wu (2004) Preparation and mechanical properties of nitrile butadiene rubber/silicate nanocomposites, Polymer, 45(16), 5729-5734.

[9] V.Petković (1999) Tehnologija gume, Gumarskohemijska industrija DD, Balkanbelt, Suva Reka. 
[10] C.Xia, N. Xiao-an, C.Jie, G.Yi-wei, L.Qian, X.B.Mi (2012) The preparation and applications of the environmentally-friendly plasticizer DOTP, Biomass chemical engineering, 46(6), 1-6.

[11] E.Langer, M.Lenartowicz, J.Kozuch, S.Waskiewicz (2012) Synthesis of terephthalic oligoesters from waste poly(ethylene terephthalate), Przemysl Chemiczny, 91(8), 1587-1590.

[12] W.Tao, L.Shiwei, L.Fudheng, Z.M.Fang, L.Lu (2012) Method for preparing plasticizer terephthalate through waste PET (polyethylene terephthalate) alcoholysis, China Patent, No. CN 102603532 A.

[13] M.Patel, J.Patel, V.Sinha (2005) Polymeric precursors from PET waste and their application in polyurethane coatings, Polymer Degradation and Stability, 90(1), 111-115.

[14] R.N.Miller, J.O.Crooke, E.D.Rietz (1952) Esters of Terephthalic Acid, Journal of the American Chemical Society, 74(16), 4214-4214.

[15] C.J.Donahue, J.A.Exline, C.Warner (2003) Chemical Recycling of Pop Bottles: The Synthesis of Dibenzyl Terephthalate from the Plastic Polyethylene Terephthalate, Journal of Chemical Education, 80(1), 79-82.

[16] A.Drah, J.Rusmirović, M.Milošević, M.Kalifa, I. Stojiljković, M.Rančić, A.Marinković (2016) Technoeconomic analysis of unsaturated polyester production from waste PET, Zaštita Materijala, 57 (4), 605-612.

\section{IZVOD}

\section{SINTEZA PLASTIFIKATORA IZ OTPADNOG PET-A ZA PRIMENU U GUMENIM PROIZVODIMA: TEHNO-EKONOMSKA ANALIZA}

$U$ radu je predstavljen postupak sinteze plastifikatora na bazi otpadnog poli(etilen tereftalata) (PET-a), kao i ekonomičnost razvijene tehnologije. Plastifikatori na bazi otpadnog PET-a: diizononil-tereftalat (DINTP), didecil-tereftalat (DDTP), dibenzil-tereftalat (DBTP) i digliceriltereftalat (DGTP) dobijeni su katalitičkom depolimerizacijom PET-a monohidroksilnim alkoholima (izononil, decil $i$ benzil alkoholi) $i$ trohidroksilnim alkoholom (glicerinom). Struktura sintetisanih plastifikatora potvrđena je primenom elementalne, FT-IR i NMR analize. Proučavane su fizičkomehaničke karakteristike (tvrdoća po Šoru, prekidna jačina i prekidno istezanje) proizvoda od gume, koje se sastoje od 100 phr-a 28\%-nog nitril butadien kaučuka (NBR) i 20,7 phr-a plastifikatora na bazi otpadnog PET-a. Dobijeni rezultati su upoređeni sa fizičko-mehaničkim karakteristikama proizvoda dobijenim korišćenjem komercijalnog plastifikatora dioktil-ftalata (DOPa). Procena ekonomskog potnecijala prikazane tehnologije za proizvodnju plastifikatora na bazi otpadnog PET-a izvršena je izradom detaljne tehno-ekonomske analize. Na osnovu određene tačke rentabiliteta doređena je minimalna cena koštanja jedinice proizvoda koja je, uz evidentno smanjen uticaj na životnu sredinu, konkurentna komercijalnom DOP-u.

Ključne reči: glikolizati otpadnog PET-a, tehnologija plasticizera, tehnologija gume, reciklaža PET-a.

Naučni rad

Rad primljen: 17. 02. 2017.

Rad prihvaćen: 25. 03. 2017.

Rad je dostupan na sajtu: www.idk.org.rs/casopis

(c) 2017 Authors. Published by Inženjersko društvo za koroziju. This article is an open access article distributed under the terms and conditions of the Creative Commons Attribution 4.0 International license (https://creativecommons.org/licenses/by/4.0/ 